Renée Walsh

4 August 2015

DH Final Paper

\title{
On the Grid: Creativity, the Digital Humanities, Oulipo, and Georges Perec
}

I do not believe that my father was...such a Poet as I shall be an Analyst; for with me the two go together indissolubly. -Ada Lovelace ${ }^{1}$

I set myself rules in order to be totally free. - Georges Perec ${ }^{2}$

In his 2014 book, The Innovators: How a Group of Hackers, Geniuses, and Geeks Created the Digital Revolution, Walter Isaacson suggests that, "the people who were comfortable at [the] humanities-technology intersection helped to create the human-machine symbiosis that is at the core of this story" (5). In other words, Isaacson suggests that the creativity inherent in the development of computing was made possible precisely by a synthesis of technological knowledge with a love of the beauty that is inherent to the arts and humanities. Isaacson notes, "I was struck by how the truest creativity of the digital age came from those who were able to connect the arts and the sciences. They believed that beauty mattered" (5). Isaacson explores how the root of this synthesis is rooted in the work of Ada Lovelace and her work with Charles Babbage on the differential machine. Based upon the Jacquard Loom, Ada saw the poetical in the recombinatory properties of the Differential Machine or the Analytical Engine. Isaacson notes that the combination of the arts and sciences is an idea, which dates back to the Renaissance, but that it is still at the heart of creativity in the post-modern era. For example,

\footnotetext{
${ }^{1}$ P. 18, Isaacson

${ }^{2}$ Source: http://www.theguardian.com/books/booksblog/2013/jul/12/oulipo-freeing-literature-tighteningrules?CMP=share_btn_link
} 
Isaacson notes that Steve Jobs said: "I always thought of myself as a humanities person as a kid, but I liked electronics... Then I read something that one of my heroes, Edwin Land of Polaroid, said about the importance of people who could stand at the intersection of humanities and sciences, and I decided that that's what I wanted to do.” (5).

In this context, this paper proposes to look at a text by the $20^{\text {th }}$ Century writer Georges Perec, and to explore why and how the Oulipo movement embodies the ideals of the digital humanities, which is to say the intersection of the sciences with the humanities. What were the ideas of Oulipo that embody the idea of the digital humanities? How can the field of digital humanities look towards the future, while being aware of its history?

In the introduction to their 2015 book, Between Humanities and the Digital, Patrik Svensson and David Theo Goldberg note that it is in the liminal "in-between" space, between the Humanities and the digital, that the most innovative work of the field is taking place:

It is in the "between" that the most interesting, creative, and provocative work of the digital and the humanistic is today being done. In this, the digital has not only prompted the humanities to open up to their own beyond, their own horizons of possibility; the humanities have likewise pushed the digital to become more than techne, more than a narrow technological application...In taking seriously the interactive, relational, and interfacing challenges of the ampersand (and) - the between of the digital and the humanities - lies the possibilities of their mutually engaged and creative transposition, their re-vision and reformation (4-5).

Looking ahead at the potential of literature and literary theory in the digital age, it will be at the intersection of the written word and the digital world that the most creative work and innovations will take place.

\section{Georges Perec and Oulipo}

Georges Perec was born at a hospital in the $19^{\text {th }}$ arrondissement of Paris in 1936. His family lived on rue Vilin of the $20^{\text {th }}$ arrondissement before the war. His father died fighting in World War II when he was four years old. His mother, Cyrla Schulevitz, brought Perec to the 
Gare de Lyon in 1942, and sent him with a Red Cross convoy to Villard-de-Lans, in unoccupied France, where he spent the rest of the war. Wearing the yellow Star of David, his mother was captured during a raid in Paris and sent to a camp in Drancy in January of 1943. The trains from Drancy were sent in the direction of Auschwitz on the $11^{\text {th }}$ of February in 1943 , where his mother died. After the war, Perec was adopted in 1945 by his paternal aunt and her husband. ${ }^{3}$ He grew up and went to school in the $16^{\text {th }}$ arrondissement of Paris, on the opposite side of the city from where he lived with his parents before the war. The immense loss experienced by Perec at a young age was explored in his writing, which was occupied with the importance of places, and our ability or inability to capture these places or moments in time. Speaking of his childhood, Perec notes that with few exceptions, he has no memories of his childhood prior to the age of $12 .^{4}$ One of these flashes of brief childhood memories before the age of 12 is the day his mother accompanied him to the Gare de Lyon to be sent to unoccupied France at four years old. He remembers his mother bought him an illustrated book that he thinks must have been about Charlie Chaplin because he thinks he remembers imagining a Charlie Chaplinesque figure on the train platform as the train moved away from the station $(48 \mathrm{~W})$.

As an adult, when not writing, Perec worked as an archivist for a medical institution in Paris. Perec was very interested in indexes and classifying items. Many of his books have indexes at the end of them. Perec died of lung cancer in 1982. A posthumous work entitled Penser/Classer or "To Think/To Classify" was published in 1985.

In November 1960, the Oulipo group (Ouvroir de la littérature potentielle) was founded of which Georges Perec was an active member. Composed of both writers and mathematicians,

\footnotetext{
${ }^{3}$ All of this biographical information is found on pages 13,31 , and 48 of the original French version of his memoir, $W$ ou le souvenir d'enfance (Editions Denoël, 1975)

4 “Je n'ai pas de souvenirs d'enfance" (13) W ou le souvenir d'enfance.
} 
the group's name stands for an "opening of potential literature." The group wished to explore and find greater creativity in literary composition through the use of constraints. Initially, the group thought about using the IBM SEA CAB 500 computer to create new texts and language (Wolff, 5).

The same year, Raymond Queneau, the founding member of the Oulipo group, created his work entitled Cent mille milliards de poèmes (A Hundred Thousand Billion Poems). The book was composed of ten sonnets cut into fourteen thin strips so that there was $10^{14}$ or one hundred trillion poem possibilities or combinations created. A Hundred Thousand Billion Poems is an interesting project in relation to the digital humanities because it sought to employ a type of combinatory poetics not unlike that which was envisioned by Ada Lovelace. Writing about Queneau's poem, William Seaman states that, "We could say that this analogue mechanism was another example of the conceptual machine" (202). Wolff notes that the members of Oulipo created at least two different types of algorithms in order to read and create new texts (11). According to Woff, "the use of the algorithm is meaningful in that the apparent unity of texts can be dismantled and give way to a multiplicity of meanings" (12). An example of a constraint employed by the Oulipo group was the "s +7 " method, in which each noun of a text was replaced by the seventh word that followed that word in the dictionary. The lipogram is another example of a constraint employed by Oulipians. Georges Perec wrote his novel La disparition, "The Disappearence," without using the letter "e" in the text. The missing letter "e" was meant to represent missing persons, such as those who died during the Holocaust.

According to Perec, he wrote four different types of texts: sociological, autobiographical, ludic, and fictive (141-142). ${ }^{5}$ So-called "ludic" or "playful" texts by Perec would be those,

\footnotetext{
${ }^{5}$ Species of Spaces (English version).
} 
which employ a Oulipian constraint to text composition. Perec classifies his sociological texts as works such as An Attempt at Exhausting a Parisian Place in which Perec sat in the Saint Sulpice square in Paris between the $18^{\text {th }}$ and the $20^{\text {th }}$ of October 1974 and attempted to record everything he saw. Here is an excerpt from page sixteen of the sixty-page text:

The 86 is going to Saint-Germain-des-Près

Dannon: Yoghurts and desserts

Demand the authentic Society Roquefort in its green oval

most people have at least one hand occupied: they are holding a bag, a small suitcase, a cabas, a cane, a leash at the end of which is a dog, the hand of a child

A truck is delivering beer in metal kegs (Kanterbraï, the beer of Judge Kanter) the 86 is going to Saint-Germain-des-Près

The 63 is going to la Porte de la Muette

A two-story bus "Cityrama"

A blue Mercedes brand truck

A brown truck Printemps Brummell ${ }^{6}$

In this type of text Perec is capturing what he named the "infra-ordinary" of life-the most banal, repetitive, and quotidian of life experiences. Perec is also attempting his experiment of attempting to "exhaust" a place, that is to say, an attempt at applying what Freud would call the "mnemic apparatus" of the pen and paper to inscribe the moment and place in memory, time, and history. ${ }^{7}$ Although seemingly banal, the text effectively captures the ebb and flow of human traffic in Saint Sulpice square, as well as documenting commerce and consumerism in the city. Furthermore, Perec inspired many other people to try their own attempts at "exhausting" a city place, whether through textual or digital film format. By "exhausting" a place through writing down everything he saw, Perec attempted to briefly capture that place and inscribe it into memory. In 2013, Yann Chapotel created a short five minute film under the name of "An Attempt at Exhausting a Parisian Place" in which a 3D cube rotates around over digital footage

\footnotetext{
${ }^{6}$ Page 16. My translation. Numbers refer to bus numbers.

7 See Freud's "Note Upon the Mystic Writing Pad."
} 
of this place over the course of a year. ${ }^{8}$ The film won prizes as an experimental movie and for its special effects. Furthermore, it is an attempt at applying a Perecquian principle to the digital age.

\section{Je me souviens or I Remember}

In 1978, Perec published a short autobiographical text called Je me souviens or "I remember," which was composed of 480 memories, many about growing up in Paris between 1950 -1968. This text was loosely inspired by American visual artist Joe Brainard's book of memories called, I Remember, which he published in 1970. Je me souviens was published by Hachette books in 1978 under the subtitle "Les choses communes I" or "Common/Everyday Things I." A translation of Perec's I Remember was not published in English until 2014. Here are some excerpts from the text:

1

I remember that Reda Caire appeared at the cinema at the Porte de Saint-Cloud

2

I remember that my uncle had an $11 \mathrm{CV}$ with the plate number $7070 \mathrm{RL} 2$

3

I remember the cinema Les Agriculteurs, the club chairs of the Caméra, and the two person seats at the Panthéon.

4

I remember Lester Young at the Club Saint-Germain; he wore a blue silk suit with a red silk lining.

5

I remember Ronconi, Brambilla, and Jésus Moujica; and Zaaf, the eternal "red lantern."

6

I remember that Art Tatum called a song "Sweet Lorraine" because he was in Lorraine during the war of 1914-1918. ${ }^{9}$

This excerpt evokes many pop-culture collective memories from the 1950s. Reda Caire was an operette singer active in 1930-1950s Paris. The Citroën 11CV (Traction Avant) was a frontwheel drive luxury car designed in 1933 whose production was halted during World War II. Lester Young was an African-American jazz saxophone player. Art Tatum was an AfricanAmerican jazz pianist who died in 1956 of kidney failure. Ronconi was an Italian theatre

\footnotetext{
${ }^{8}$ The film is available at the following link: https://vimeo.com/60275721

${ }^{9}$ My translation.
} 
director who was especially active in the 1960s-1970s. Brambilla was an Italian Grand Prix motorcycle racer who won first place in a 1963 race. Jésus Moujica was a Spanish-French cyclist who died in 1950 in a traffic accident in Montélimar while riding his bicycle. Zaaf, whose full name was Abdel-Kader Zaaf, was a French cyclist who participated four times in the Tour de France. He finished in last place in the 1951 Tour de France.

If we are to make some sense out of these first six out of 480 memories in $\mathrm{Je}$ me souviens, we can note that some of these popular figures experienced tragic circumstances. The stop in the production of Citroën $11 \mathrm{CV}$ during World War II is also symbolic of a time period during which many lives were lost, notably Perec's parents. The post World War II period is also the beginning of what in France is called Les Trente Glorieuses, the thirty glorious years of economic boom that France experienced from the Marshall Plan until the 1973 Suez oil crisis. The popular memories in this text are succinct phrases that bring to mind Roland Barthes' Mythologies, written between 1954 and 1956, which he intended to be, "an ideological critique about the language of pop culture/ mass culture, while also acting as a semiological deconstruction of this language" (7). Like Perec, Barthes was preoccupied by events mentioned in the news, advertising, and popular culture and he wished to explore and deconstruct the "myths of daily French life" (9).

Evidently, Je me souviens is highly hypertextual in that it is constantly referring to references outside of the succinct printed text. The text is interactive with the reader, because the reader must try to recall these memories if she lived during the time remembered. Otherwise, if reading this text in 2015 , the reader would search the hypertextual references online in order to understand their meaning and context. Je me souviens is a text that is marked by nostalgia and repetition because the phrase "Je me souviens" starts each memory. The text also makes 
repeated hypertextual references to pop culture, places, and historical events. In this way the project fits into the Perecquian oeuvre, which exists in many ways as an interactive game with its reader. Furthermore, the hypertextual nature of the writing is analogous to the hyper-networked state of the modern and post-modern era. After all, Tim Berners-Lee utopic vision of the semantic web is predicated upon this type of semantic interconnectedness ad-infinitum. As Manual Lima states in his book Visual Complexity: Mapping Patterns of Information:

The rhizomatic model is a significant influence in postmodern thinking...But perhaps one of the most famous demonstrations of the principle's applicability is the hypertext. Pertaining to any text with references (hyperlinks) to other texts, hypertext is the fundamental building block of the World Wide Web-arguably the largest rhizomatic system ever created by man. But rhizomatic theory also helps us to apprehend the intricacies of the world: the rhizome is not a self-imposed conjectural view on our existence, but a fundamental topology of nature and an underlying element to the complex fabric of life (44).

According to Alison James, the rhizomatic labyrinth is an integral format to the work of Perec. This type of labyrinth, which is mentioned by Umberto Eco, "has no center, no periphery, and no exit, because it is potentially infinite" (158). Furthermore, James explains: "...the labyrinth, as both a metaphor for the text and an allegory of the subject's relationship to the world, engages the question of the connections between knowledge, representation, and literary form" (158). In other words, the labyrinth is emblematic of the active relationship between the writer and the reader. Finally, James notes that, "From Joyce to Kafka to Garcia Marquez, the labyrinthespecially of the rhizomatic type defined by Eco-has become a commonplace of the modernist imagination and a figure of epistemological crisis" (158). In Perec's case, the epistemological crisis was his search for meaning and memory in the consumer culture boom of post-World War II Paris.

In writing about the visual artist Joe Brainard (after whom Perec was inspired to write $J e$ me souviens), Daniel Worden states that the visual form of the grid is inherent to the post- 
modern condition. Worden notes that the importance of the grid format in art coincides with the increased visibility of graphic novels in the $20^{\text {th }}$ Century. Worden refers to Rosalind Krauss, who states that the grid always acts as repetitive and mechanically reproducible. For Worden and Krauss, the grid is not inherently a format for creativity, which is where their interpretation diverges from Perec and Oulipo.

In 1984, Warren Motte noted that the grid as represented in the format of crossword puzzles and games, was inherent to the work of Georges Perec. Motte notes that, "Perec suggests...that the crossword puzzle is revelatory not only of the linguistic, but of the poetic" (823). Perec created heterogrammatic poetry modeled after crossword puzzles. The structure and plot of his most famous novel, Life, A User's Manual, was modeled after the Knight's Tour of a chess board. Perec was also strongly influenced by the Japanese game of Go when creating his writing: "There is only one activity to which one can reasonably compare to Go: one understands that this activity is writing." (Motte 824). Furthermore, Motte states:

...Perec is convinced of the primacy of form...the point must be made here that the form of La Vie mode d'emploi is remarkably similar to that of a crossword puzzle, as well as that of Perec's poetry: it constitutes a heuristic (and ludic) system wherein the grid serves to structure the play of combinatory poetics (830)

It is here that we come back to the ideas of Ada Lovelace. Much like with the analytical machine, Oulipian methods are also interested in a "combinatory poetics," which intermingles the arts and the sciences.

\section{Part II: Mapping and the Digital Humanities}

The Digital Humanities have their roots in humanities computing and the St. Thomas Aquinas concordance of Father Roberto Busa in 1949, which sought to analyze and lemmatize 
11 million words of Medieval Latin (Hockey 4). One year after Alan Turing published his essay on "Intelligent Machinery," Busa travelled to the U.S. to meet with Thomas J. Watson of IBM. Although a computational approach to literature dates to the 1850 s, Busa was a pioneer in creating concordances with the help of punch cards and early computers. The so-called humanities computing field began and the first professional organizations were formed in the 1960s and the 1970s.

Despite all of this history, it has only been in the past 15-20 years that the so-called field of digital humanities has exponentially grown and expanded. In 2005, Franco Moretti published Graphs, Maps, Trees: Abstract Models for a Literary Theory and in 2013 he published Distant Reading. In the "Maps" chapter of GMT, Moretti asks: "There is a very simple question about literary maps: what exactly do they do? What do they do that cannot be done with words, that is; because, if it can be done with words, then maps are superfluous...Do maps add anything, to our knowledge of literature? (35). In his analysis of the geographic locations of characters in Victorian novels, Moretti proves that maps do add to our understanding of literature.

In his 2013 book entitled Macroanalysis: Digital Methods \& Literary History, Matthew L. Jockers argues that we need to take a hybrid approach to literary study, one that neither neglects textual close reading, nor the expanded possibilities offered by approaches such as TEI and GIS:

Like it or not, today's literary-historical scholar can no longer risk being just a close reader: the sheer quantity of available data makes the traditional practice of close reading untenable as an exhaustive or definitive method of evidence gathering... The same argument, however, may be leveled against the macroscale; from thirty thousand feet, something important will inevitably be missed. The two scales of analysis, therefore, should need to coexist (Jockers 9).

Computer based modeling of literature seems to be a valid way of analyzing literature given that one already possesses a solid foundation in literary analysis and literary theory. For example, 
when approaching $20^{\text {th }}$ Century text like Perec's Je me souviens, one needs to understand that the hypertextual references to consumerism could be analyzed by Marxist theorist like Baudrillard or by structuralist/post-structuralist theory like in Roland Barthe's Mythologies. One could also reference Deleuze and Guattari's One Thousand Plateaus in order to describe the so-called "rhizomatic" effect of the text.

\section{Perec and Geographic Space:}

Ahead of his time, Perec understood the importance of interrogating the space we live in, and the space that we pass through. As Perec notes in the "Measures" chapter of his book Species of Spaces:

Right here, at this moment, it wouldn't be altogether impossible for me to determine my position in degrees, minutes, seconds, tenths and hundredths of a second: somewhere in the region of $49^{\circ}$ north latitude, somewhere in the region of $2^{\circ} 10^{\prime}$ 14.4" east of Greenwich (or only a few fractions of a second west of the Paris meridian), and a few dozen meters above sea-level (82).

What is the point of noting the latitude and longitude of a person in relation to space, whether in a fictional or non-fictional work of writing? Perec answers this question with the following observation:

Now and again...we ought to ask ourselves exactly where exactly we are, to take our bearings, not only concerning our state of mind, our everyday health, our ambitions, our beliefs...but simply concerning our topographical position, not so much in relation to the axes cited above, but rather in relation to a place or person we are thinking about, or that we shall thus start thinking about (83). ${ }^{10}$

For Perec, space is constantly in flux, in movement, and unstable. Like Odysseus, he has nostalgia for a place like home that would be unchangeable, immutable, and rooted: "I would like there to exist places that are stable, unmoving...places that might be points of reference, of

\footnotetext{
${ }^{10}$ Espèces d'espaces. My translation.
} 
departure, of origin" (91). Nevertheless, he notes that: "such places don't exist, and it's because they don't exist that space becomes a question... Space is a doubt: I have constantly to mark it, to designate it. It's never mine, never given to me, I have to conquer it" (91). For Perec, space is like shifting sands, and space is also like a puzzle. For him writing is the only way of trying to leave a trace, a mark upon that which one cannot possess (92).

For Perec, the "infra-ordinary," the banal observations of the quotidian carry significant meaning when one begins to interrogate their so-called banality. When Perec sat in a place and tried to record everything he saw, he was in a way collecting data. In "The Street" chapter of Species of Spaces, Perec gives some advice as to how one can attempt to look at the ordinary:

From time to time, observe the street with some systematic concern...Apply yourself. Take your time. Note the place...the time...the date...the weather...Force yourself to write down what is of no interest, what is the most obvious, the most ordinary...Detect a rhythm: the passing of cars...Count the cars. Look at the license plates. Distinguish between the cars registered in Paris from the rest. Note the absence of taxis precisely when there seems to be a lot of people waiting for one (50$51)$.

For Perec all of this banal information contains meaning and significance when analyzed. For example, he invites observers to ask why buses choose certain routes across the city, and why they have a certain number. In this way, Perec is interested in city planning, architecture, and all of the networks that link a city:

...strive to picture to yourself, with the greatest possible precision, beneath the network of streets, the tangle of sewers, the lines of the Métro, the invisible underground proliferation of conduits (electricity, gas, telephone lines, water mains, express letter tubes), without which no life would be possible on the surface (54).

As stated before, Perec sees the significance and the meaning behind the seemingly banal. For example, which bus goes from point A to point B? What is the shortest route home in the 
afternoon? Why? Perec's preoccupation with quotidian details looks like data collection and interpretation as it is relevant to the digital humanities today.

\section{Mapping Je me souviens}

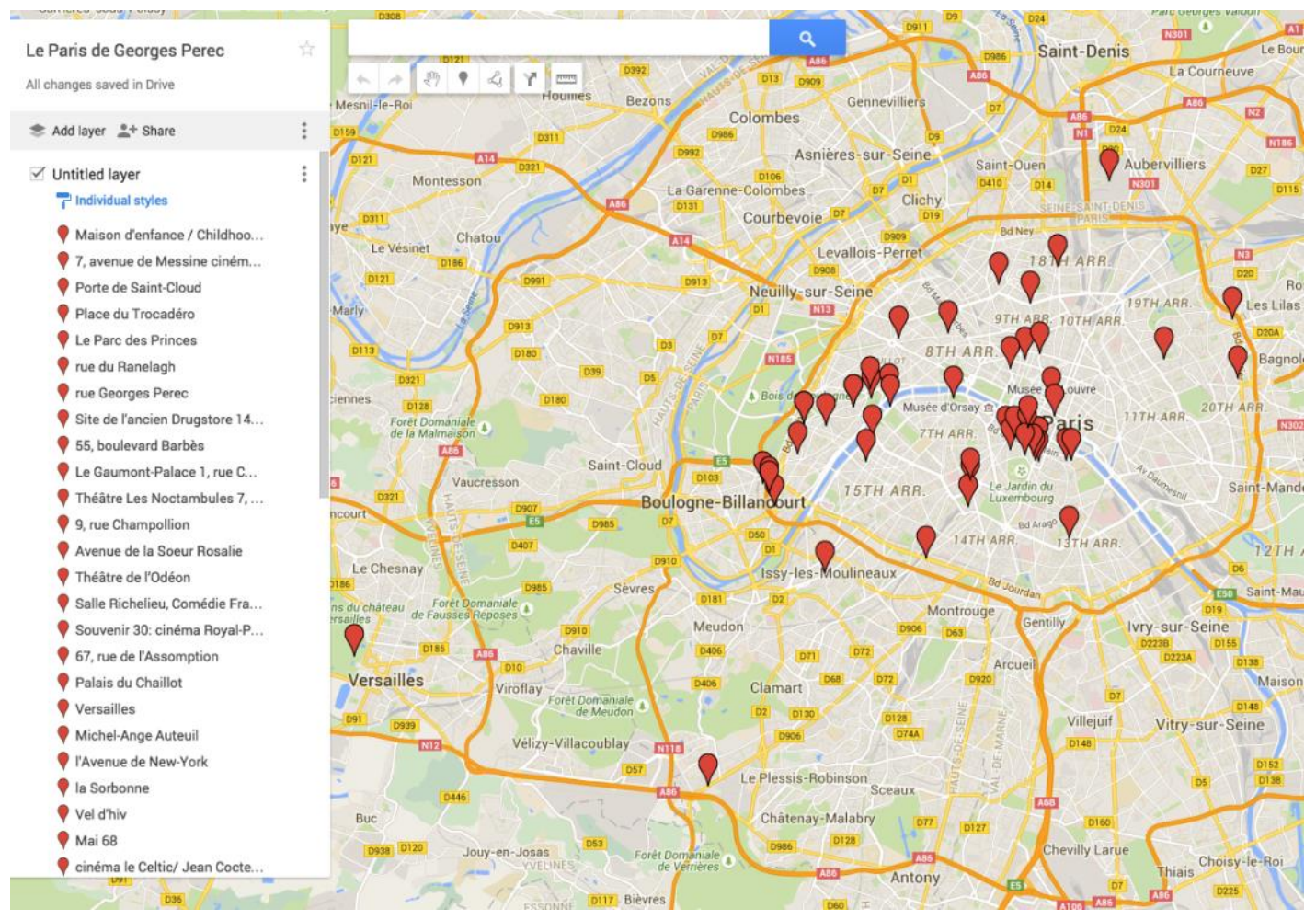

For this class I mapped on Google Maps every mention of a specific geographic reference to a place that is found in the 480 memories of Je me souviens. In the future, this would be better completed with GIS software, but due to a lack of time, I started by simply mapping on Google Maps. Each mark on the map follows in principle with the Perecquian idea of inscribing one's memories in time and place, but this time in digital format. In some cases, I had to search online to find the address of a former café, cinéma, or theatre that existed in the 1950s or 1960s, but now is the location of a different type of commerce.

The collective impact of these places is that one can see, and on a grid format, the places that Perec frequented the most during his late childhood and adolescence in Paris. It would be 
interesting to explore the possible lines and routes between the places marked on the map in order to establish an image of possible walking trajectories between places. Furthermore, one could layer digital images of what these places looked like in the 1950s or 1960s with what they look like today.

One can conclude from looking at the map of memories, that the majority of the memories take place either in the Latin Quarter, or near the neighborhood where Perec lived with his aunt and uncle. Many of the memories mention theatres and cinemas in Paris as well. Image $\underline{\mathbf{A}}$ shows the memories from the $5^{\text {th }}$ and $6^{\text {th }}$ arrondissements. Image B shows memories from the $16^{\text {th }}$ arrondissement where Perec lived with his aunt and uncle and went to school. Image C shows memories from the $2^{\text {nd }}-18^{\text {th }}$ arrondissements.

\section{Image A: Latin Quarter: $5^{\text {th }}$ and $6^{\text {th }}$ Arrondissement Memories}

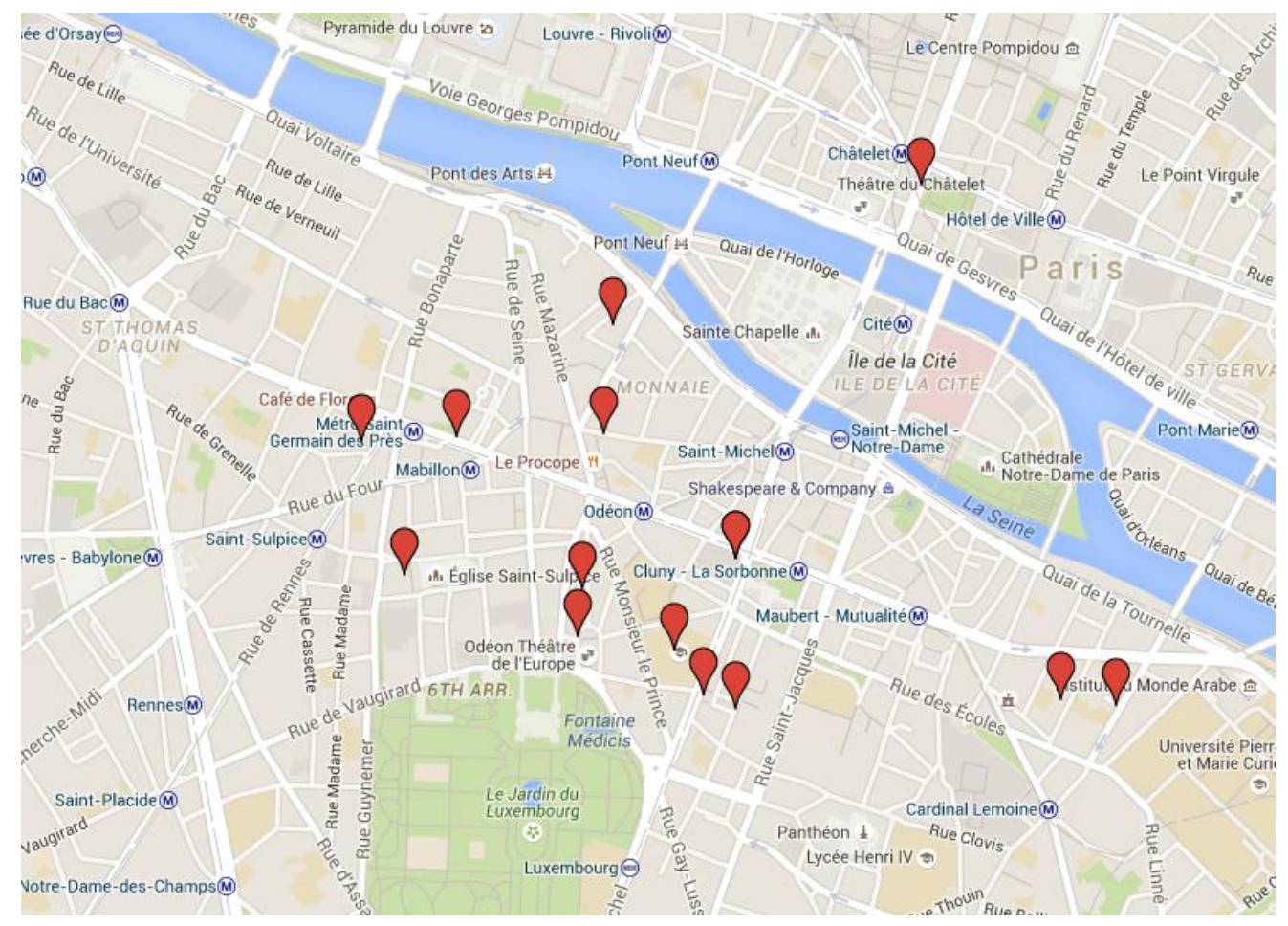


Image B: $16^{\text {th }}$ Arrondissement Memories

$\underline{\text { Image C: 2e, 8e, 9e,18e Memories }}$
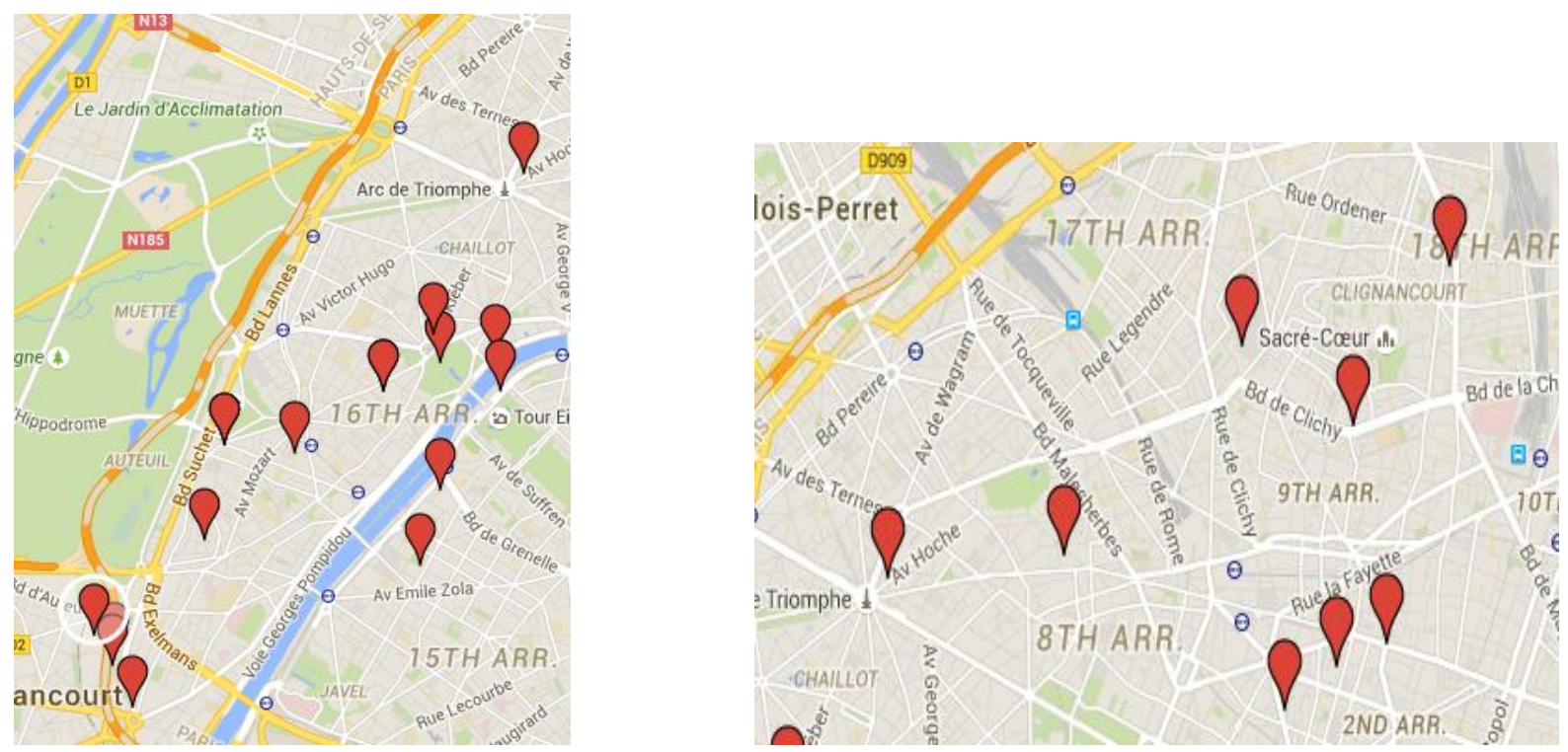

Notably, there are no memories from the $20^{\text {th }}$ arrondissement, where Perec lived with his family before World War II. The majority of the memories are situated around places where Perec went to see movies, plays, to go shopping, and to see sporting events. To summarize, the memories are situated around places of cultural fun, diversion, and amusement in 1950s and 1960s Paris. $\underline{\text { Image B }}$ shows memories situated around where Perec lived and went to primary and secondary school. Image $\mathbf{C}$ is situated around theatres and places to go shopping in Paris.

Looking at these places on the map, we can ask the question posed by Franco Moretti, “Do maps add anything, to our knowledge of literature?" (GMT, 35). In this case, we can affirm that these maps document Perec's history of social and cultural diversions during a historical period of dramatic economic transformation. As Kristen Ross notes, "The unusual swiftness of French postwar modernization seemed to partake of the qualities of what Braudel has designated as the temporality of the event: it was headlong, dramatic, and breathless" (4). Furthermore, the postwar transformation of France occurred through industrialization, advertising, construction, 
and its documentation in popular culture such as in movies and songs. Kristen Ross notes: “...in postwar France the banalization of car travel coincided with the banalization of the cinema; Georges Perec, for example, locates the historical newness of his young adult characters in the 1960s in terms of their relation to cinema" (38). Ross cites an instance from Perec's novel Les choses, where the bourgeois couple are "cinéphiles" who love to go to the cinema:

Above all they had the cinema. ..They belonged by their age...to this first generation for whom the cinema was more than just an art, it was an evidence; they has always known it, not as some mumbling form, but from its masterpieces, its mythology...They loved the images...how they drew them in, ravished, and fascinated them. They loved the conquest of space, of time, of movement, they loved the whirlwind of New York streets... $(58-59)^{11}$

After reading the former passage from Perec's novel Things: A Story of the 60s and looking at the map of memories from Je me souviens, one can begin to establish more commonalities between Perec's memories of the 1950s and 1960s, and the plots of his various novels which take place during the same time frame.

There is much more that can be done with literary mapping and interpretation than what was briefly discussed here in relation to Georges Perec's Je me souviens. Nevertheless, if Perec was still alive today, he undoubtedly would have been amused by all of the technological possibilities now available to act as a mnemic apparatus or memory aids in attempting to capture our everyday space.

\section{Francophone Digital Humanities - Les Humanités Numeriques Francophones}

At this point, there seems to be significantly more digital humanities work done in English than in French, but there are still some projects that are beginning to emerge. Duke University's French department has recently launched a website with several projects to make

\footnotetext{
${ }^{11}$ My translation. Les choses: une histoire des années soixante. Paris : Julliard, 1965.
} 
significant cultural resources available online. ${ }^{12}$ Stanford University's literary lab has mapped Balzac's Comédie Humaine. ${ }^{13}$ While it is often easier to complete digital humanities projects with texts in the public domain, in the future, more contemporary texts will begin to be examined through the lens of the digital humanities. Undoubtedly, the best practices in the field will combine close reading with distant reading, or micro and macro reading, in order to offer the best interpretation possible. In the words of Ada Lovelace, "Analysts" and "Poets" shall work together, or each literary theorist will employ these so-called "combinatory poetics."

\section{Works Cited and Bibliography:}

Adair, Gilbert. "The Eleventh Day: Perec and the Infra-ordinary." Review of Contemporary Fiction 29(2009).

Barthes, Roland. Mythologies. Paris: Editions de Seuil, 1957.

Brock, Kevin. "Critical Essay_ One Hundred Thousand Billion Processes: Oulipian Computation and the Composition of Digital Cybertexts." technoculture: an online journal of technology in society 2 (2012). Accessed 30 July 2015. Available: http://tcjournal.org/drupal/vol2/brock

Chapotel, Yann. « Tentative d'épuisement d'un lieu parisien. » Accessed 29 July 2015. Available : https://vimeo.com/60275721

«Cinémas de Paris ». Accessed 29 July 2015. Available : http://www.parislouxor.fr/cinemasdeparis/

Gallix, Steve. "Oulipo: freeing literature by tightening its rules." The Guardian. Accessed 3 August 2013. Available : http://www.theguardian.com/books/booksblog/2013/jul/12/oulipofreeing-literature-tightening-rules?CMP=share_btn_link

Hockey, Susan. A Guide to Computer Applications in the Humanities. Baltimore: John Hopkins UP, 1980.

12 http://www.francophonedh.com/ See also: http://pireh.univ-paris1.fr/DHfrancophone/index.php

13 http://web.stanford.edu/group/humdesignlit/cgi-bin/mappingbalzac/ 
Hockey, Susan. "The History of Humanities Computing” in A Companion to Digital

Humanities, ed. Susan Schreibman, Ray Siemans, and John Unsworth, 3-19. Malden: Blackwell Publishing, 2004

Hodges, Steve. "Revealing Code : What Can Language Teach Software?"

M.S. Information Design and Technology Thesis, Georgia Institute of Technology, May 2004.

Available: http://www.borderschess.org/Perec.pdf

INA (Institut National de l'Audiovisuel). "Le Congrès de Versailles: L'Election de René Coty." Accessed 29 July 2015. Available : http://fresques.ina.fr/jalons/fichemedia/InaEdu00024/le-congres-de-versailles-l-election-du-president-coty.html

Isaacson, Walter. The Innovators: How a Group of Hackers, Geniuses, and Geeks Created the Digital Revolution. New York: Simon and Schuster, 2014.

James, Alison. Constraining Change: Georges Perec and the Oulipo. Evanston: Northwestern UP, 2009.

Jockers, Matthew L. Macroanalysis: Digital Methods and Literary History. Urbana: U of Illinois Press, 2013.

Lang, Anouk. “Mapping John Glassco’s Memoirs of Montparnasse.” Accessed 29 July 2015. Available: http://aelang.net/projects/glassco.htm

Lima, Manuel. Visual Complexity: Mapping Patterns of Information. New York: Princeton Architectural Press, 2011.

Moretti, Franco. Distant Reading. London: Verso Books, 2013.

Moretti, Franco. Graphs, Maps, Trees. London : Verso Books, 2005.

Magné, Bernard. «Georges Perec on the Index ». Yale French Studies 105 ( 2004): 72-88

Motte, Warren F. « Georges Perec on the Grid. » The French Review 57 (1984): 820-832

Perec, Georges. Les choses: une histoire des années soixante. Paris : Julliard, 1965.

Perec, Georges. Espèces d'espaces. Paris: Editions Galilée, 1974/2000.

Perec, Georges. Je me souviens. Paris: Hachette, 1978.

Perec, Georges. Species of Spaces and Other Pieces. New York : Penguin Classics, 2008.

Perec, Georges. W ou le souvenir d'enfance. Editions Denoël, 1975. 
Perec, Georges. Tentative d'épuisement d'un lieu parisien. Union Générale d'Editions (Christian Bourgeois Editeur), 1975.

Ross, Kristin. Fast Cars, Clean Bodies: Decolonization and the Reordering of French Culture. Cambridge: MIT Press, 1996.

Rudick, Nicole. «I Remember Georges Perec. » The Paris Review. 30 July 2014. Accessed 30 July 2015. Available: http://www.theparisreview.org/blog/2014/07/30/i-remembergeorges-perec/\#comments

Seaman, William Curtis. "Recombinant Poetics: Emergent Meaning as Examined and Explored Within a Specific Generative Virtual Environment." Centre for the Advanced Inquiry in the Interactive Arts.

Available:http://projects.visualstudies.duke.edu/billseaman/pdf/recombinantPoeticsDis.p df

Svensson, Patrik and Goldberg, David Theo, editors. Between Humanities and the Digital.

Cambridge: MIT Press, 2015.

Wolff, Mark. "Reading Potential: The Oulipo and the Meaning of Algorithms." DHQ: Digital Humanities Quarterly (1): 2007. Available:

http://www.digitalhumanities.org/dhq/vol/1/1/000005/000005.html

Worden, Daniel. "Joe Brainard's Grid, or, the Matter of Comics." Nonsite.org (15): March 1, 2014. Available: http://nonsite.org/article/joe-brainards-grid-or-the-matter-of-comics 